\title{
KORELASI STRATEGI MULTIPLE INTELLIGENCES DENGAN KUALITAS PEMBELAJARAN PENDIDIKAN AGAMA ISLAM PADA SMPN DI WATAMPONE
}

\author{
Samsinar \\ Jurusan Tarbiyah STAIN Watampone \\ Jalan Hos-Cokroaminoto Watampone \\ Email: samsinarakbar@gmail.com
}

\begin{abstract}
Abstrak:
Tujuan penelitian ini adalah untuk mengetahui gambaran strategi multiple intelligences guru Pendidikan Agama Islam pada SMPN di Watampone, kualitas pembelajaran Pendidikan Agama Islam pada SMPN di Watampone, dan korelasi antara keduanya. Penelitian ini dilaksanakan pada sembilan SMPN di Watampone dengan jumlah guru Pendidikan Agama Islam sebanyak 34 orang. Teknik analisis yang digunakan adalah analisis deskriptif kuantitatif dan analisis koefisien korelasi product moment. Hasil penelitian menunjukkan bahwa strategi multiple intelligences telah diterapkan dengan baik oleh guru Pendidikan Agama Islam pada SMPN di Watampone walaupun belum maksimal melalui berbagai aktivitas penekanan strategi kecerdasan. Hasil penelitian ini juga menunjukkan bahwa kualitas pembelajaran Pendidikan Agama Islam pada SMPN di Watampone menekankan pada kualitas proses pembelajaran Pendidikan Agama Islam yang dimulai dengan perencanaan, pelaksanaan, penilaian dan pengawasan proses pembelajaran. Sedangkan jika dikorelasikan antara keduanya maka ada hubungan positif dan signifikan.
\end{abstract}

\begin{abstract}
:
The objectives in this study namely to know describe the strategy of multiple intelligences of Islamic Education teachers at Junior High Schools in Watampone, quality learning Islamic education at Junior High Schools in the Watampone, and correlation. This research conducted at the Junior High School in Watampone the number of teachers of Islamic education as many as 34 people. Analysis technique used is quantitative descriptive analysis and product moment correlation coefficient. The results showed that the strategy of multiple intelligences has been well implemented by teachers of Islamic education in junior high schools in Watampone although not maximal suppression activity through various intelligence strategy. The results of this study also showed that the quality of teaching Islamic education emphasizes on the quality of the learning process of Islamic education that begins with the planning, implementation, assessment, and monitoring of the learning process. whereas if correlated then there is a positive and significant relationship strategies on the quality of learning multiple intelligences of Islamic Education in Junior High School in Watampone.
\end{abstract}

Kata kunci:

Strategi Multiple Intelligences, Kualitas Pembelajaran, Pendidikan Agama Islam

PEMBELAJARAN merupakan aktivitas atau proses yang sistematis dan sistemik yang terdiri atas beberapa komponen. Komponen tersebut adalah tujuan pembelajaran, guru, siswa, perencanaan pembelajaran sebagai segmen kurikulum, strategi 
pembelajaran, media pembelajaran, dan evaluasi pembelajaran. ${ }^{1}$ Tiap-tiap komponen pembelajaran di atas tidak bersifat parsial (terpisah) atau berjalan sendiri-sendiri, tetapi harus berjalan secara teratur, saling bergantung, komplementer, dan berkesinambungan.

Salah satu komponen yang sangat berpengaruh dalam proses pembelajaran adalah strategi atau metode mengajar yang digunakan guru dalam pembelajaran. Strategi adalah suatu cara kerja yang sistemik dan umum serta berfungsi sebagai alat untuk mencapai tujuan. Strategi dapat diartikan sebagai a plan, method, or series of activities designed to achieves a particular educational goal. ${ }^{2}$ Jadi, strategi adalah suatu perencanaan, metode atau berbagai aktivitas yang dirancang khusus untuk mencapai tujuan pendidikan. Dengan demikian, strategi pembelajaran adalah perencanaan, metode atau rangkaian kegiatan yang dirancang untuk mencapai tujuan pembelajaran tertentu.

Beberapa strategi pembelajaran telah diterapkan oleh guru Pendidikan Agama Islam (PAI) pada SMPN di Watampone, termasuk strategi multiple intelligences. Strategi multiple intelligences adalah sebuah strategi guru PAI yang menekankan beberapa kecerdasan siswa yaitu strategi kecerdasan linguistik, logis-matematis, musik, interpersonal, intrapersonal, spasial-visual, naturalis, kinestetik, dan eksistensialis atau spiritualis.

Hasil survei awal yang telah peneliti lakukan adalah guru PAI lebih memfokuskan pada dua atau hanya tiga kecerdasan saja ketika mengajar. Begitu juga ketika melakukan penilaian. Ketiga kecerdasan yang dimaksud yaitu linguistik, logismatematis, dan spiritual. Ketika siswa memiliki ketiga kecerdasan ini guru PAI menganggap bahwa siswa inilah yang cerdas. Pada hal kecerdasan itu tidak hanya diukur pada ketiga kecerdasan di atas, tetapi ada 9 kecerdasan yang dimiliki oleh setiap siswa, dan dari ke-9 kecerdasan tersebut ada beberapa yang menonjol. Ketika seorang guru PAI pada SMPN di Watampone memahami kecerdasan siswa dengan baik dan mengajar sesuai dengan kecerdasannya, guru akan berhasil dalam pembelajarannya. Selanjutnya, ada anggapan bahwa pembelajaran PAI hanya difokuskan pada spiritual saja.

Selain itu, ada indikasi bahwa guru PAI lebih banyak mengajar dengan gayanya sendiri, tidak memperhatikan gaya belajar siswanya. Pada hal, guru harus mengajar dengan memperhatikan potensi, bakat, dan minat yang dimiliki siswa. Ketika guru memperhatikan hal di atas, siswa akan berhasil dalam belajarnya, yaitu memahami materi pembelajan dengan mudah dan cepat, tidak bosan, menyenangkan, dan bersemangat dalam belajar. Ketika semua ini tercapai, kualitas pembelajaran Pendidikan Agama Islam akan meningkat.

Selanjutnya, mengenai kualitas pembelajaran PAI pada SMPN di Watampone, ada indikasi bahwa guru PAI pada SMPN di Watampone lebih memfokuskan kualitas pembelajarannya pada proses pembelajaran PAI. Pada hal kualitas pembelajaran tidak hanya dapat dilihat dari segi proses tapi input dan outputnya juga.

Berdasarkan latar belakang di atas, rumusan masalah dalam penelitian ini adalah: 
1. Bagaimana gambaran strategi multiple intelligences guru PAI pada SMPN di Watampone?

2. Bagaimana kualitas pembelajaran PAI pada SMPN di Watampone?

3. Apakah terdapat hubungan strategi multiple intelligences terhadap kualitas pembelajaran PAI pada SMPN di Watmpone?

Dari ketiga permasalahan tersebut, tujuan penelitian dapat dirumuskan sebagai berikut:

1. Untuk mengetahui gambaran strategi multiple intelligences guru PAI pada SMPN di Watampone

2. Untuk mengetahui kualitas pembelajaran PAI pada SMPN di Watampone.

3. Untuk mengetahui hubungan antara strategi multiple intelligence dengan kualitas pembelajaran pada SMPN di Watampone.

\section{TINJAUAN TEORETIS}

\section{Strategi Multiple Intelligences}

Guru memiliki andil yang sangat besar terhadap keberhasilan pembelajaran di sekolah. Guru sangat berperan dalam membantu perkembangan siswa untuk mewujudkan tujuan hidupnya secara optimal. Minat, bakat, kemampuan, dan potensi-potensi yang dimiliki siswa inilah yang dikembangkan oleh guru di sekolah. Oleh karena itu, guru harus memperhatikan siswa secara individual, karena antara satu siswa dengan siswa yang lain memiliki perbedaan yang sangat mendasar.

Guru harus mampu memberikan kemudahan belajar kepada siswa, agar mereka dapat mengembangkan potensinya secara optimal. Guru juga seharusnya kreatif, profesional, dan menyenangkan. Ia harus memposisikan diri sebagai orang tua yang penuh kasih pada siswanya, sebagai teman, tempat mengadu, dan mengutarakan perasaan siswa. Guru juga harus menjadi fasilitator yang selalu siap melayani siswa sesuai dengan bakat, minat, dan kemampuannya. Selain itu, guru harus mampu memberi sumbang saran kepada orang tua agar siswa agar dapat mengetahui permasalahan yang dihadapi oleh anaknya dan memberi saran pemecahannya, termasuk memupuk rasa percaya diri, berani dan bertanggung jawab. Guru juga harus membiasakan siswa untuk saling berhubungan (bersilaturrahmi) dengan orang lain secara wajar, mengembangkan proses sosialisasi yang wajar antar siswa, orang lain dan lingkungannya, serta mengembangkan kreativitas. ${ }^{3}$

Untuk memenuhi tuntutan di atas, guru harus mampu memaknai pembelajaran, serta menjadikan pembelajaran sebagai ajang pembentukan kompetensi dan perbaikan kualitas pribadi siswa. Oleh karenanya, guru harus memahami berbagai strategi dalam pembelajaran dan menerapkannya sehingga dapat mencapai tujuan pembelajaran baik secara efektif maupun secara efisien.

Bagi seorang guru, strategi dapat dijadikan pedoman dan acuan yang sistematis dalam pelaksanaan pembelajaran. Bagi siswa (pengguna strategi pembelajaran) dapat mempermudah proses belajar. ${ }^{4}$ Salah satu strategi pembelajaran yang memudahkan siswa dalam belajar adalah strategi multiple intelligences. Multiple intelligences atau 
disebut juga kecerdasan majemuk adalah sebuah teori psikologi yang dicetuskan oleh Howard Gardner pada tahun 1983. Teori ini telah memberikan sumbangan yang cukup besar bagi dunia pendidikan yang sebelumnya lebih banyak memberikan fokus perhatian hanya pada sisi linguistic dan mathematical intelligence (kecerdasan bahasa dan matematik) saja. Menurutnya, IQ bukan satu-satunya alat ukur untuk mengetahui kemampuan seseorang tetapi ada kecerdasan-kecerdasan lain yang juga amat penting yaitu kecerdasan bahasa, logis-matematik, musik, interpersonal, intrapersonal, spasial-visual, naturalis dan kinestetik. ${ }^{5}$

Strategi multiple intelligences merupakan strategi mengajar dalam sebuah proses pembelajaran yang menitikberatkan pada kecocokan antara gaya mengajar guru dan gaya belajar siswa, sehingga tujuan pembelajaran tuntas. ${ }^{6}$ Strategi multiple intelligences adalah salah satu strategi pembelajaran yang menghargai keunikan setiap siswa melalui berbagai potensi atau kecerdasan yang dimiliki siswa, dan berbagai variasi cara belajar siswa.

Guru yang mengajar dengan strategi multiple intelligences adalah guru yang mempertahankan tujuan pembelajarannya yang kuat dalam pikiran, sekaligus mengganti metode presentasinya dari linguistik ke visual-spasial ke musik dan sebagainya, bahkan sering menggabungkannya dalam beberapa kecerdasan dengan cara kreatif. ${ }^{7}$

Guru dengan strategi ini, juga memberikan pengalaman menggunakan keterampilan tangan, baik yang melibatkan siswa untuk bangkit dan bergerak, mengedarkan sebuah artefak di dalam kelas untuk membangkitkan minat pada materi yang diteliti, atau meminta siswa membangun sesuatu yang nyata untuk mengungkapkan pemahaman mereka. Selain itu, guru juga meminta siswa berinteraksi satu sama lain dengan cara yang berbeda, misalnya berpasangan, membentuk kelompok kecil, atau kelompok besar; merencanakan waktu bagi siswa untuk terlibat dalam refleksi diri, melakukan pekerjaan sendiri, atau menghubungkan pengalaman dan perasaan pribadi mereka ke materi yang sedang dipelajari, dan menciptakan kesempatan-kesempatan agar proses pembelajaran terjadi melalui makhluk hidup. ${ }^{8}$

Strategi multiple intelligences merupakan strategi yang dapat membantu guru dalam mengidentifikasi dan berempati pada minat dan kemampuan setiap siswa. Ia bukanlah sarana untuk mempersempit pendidikan, melainkan sebagai strategi dalam memperbesar, memperluas dan memperbanyak serta memperkaya ranah-ranah pengetahuan yang terdapat di sekolah. ${ }^{9}$

Ada beberapa cakupan dalam strategi multiple intelligences yaitu:

\section{Strategi Linguistic Intelligence (Strategi Kecerdasan Bahasa)}

Strategi ini adalah sebuah strategi yang menekankan pada penggunaan bahasa, baik lisan maupun tulisan secara efektif dan akurat. Untuk mengembangkan strategi kecerdasan ini, beberapa hal yang bisa dilakukan guru dalam pembelajaran yaitu brainstorming (memberi sumbang pendapat), storytelling (bercerita), menulis jurnal, dan penerbitan. Dengan aktivitas ini maka guru telah mengembangkan strategi kecer- 
dasan linguistik siswa dan siswa akan termotivasi untuk terus mengembangkan kecerdasan ini.

\section{Strategi Logical-Mathematical Intelligence (Strategi Kecerdasan Logika)}

Strategi kecerdasan logika adalah sebuah strategi yang digunakan guru dalam pembelajaran dengan menekankan pada aspek pemecahan masalah, berpikir kritis, aktivitas membuat kategorisasi serta melatih ketelitian siswa. Ada beberapa aktivitas yang dapat dilakukan guru dalam mengembangkan strategi kecerdasan ini yaitu berpikir kritis, pertanyaan Socrates, dan problem solving.

\section{Strategi Visual-Spatial Intelligence (Strategi Kecerdasan Gambar-Ruang)}

Strategi kecerdasan gambar-ruang adalah salah satu strategi yang digunakan guru dalam pembelajaran dengan menampilkan gambar-gambar atau presentasi visual. Ada beberapa aktivitas guru dalam mengembangkan strategi kecerdasan ini yaitu kartu indeks, membuat sketsa, display class, dan movie learning.

\section{Strategi Bodily-Kinesthetic Intelligence (Strategi Kecerdasan Gerakan Tubuh)}

Strategi kecerdasan kinestetik adalah sebuah strategi yang digunakan guru dalam pembelajaran yang menekankan pada gerakan tubuh dan kontrol tubuh. Strategi ini biasa juga disebut strategi kecerdasan fisik. Strategi kecerdasan ini menyempurnakan tiga strategi kecerdasan yang berhubungan dengan objek yaitu strategi kecerdasan logika, visual-spasial, dan strategi kecerdasan kinestetik sendiri. ${ }^{10}$

Tujuan dari strategi kecerdasan ini adalah agar siswa terampil dalam mengungkapkan suatu ide, pemikiran dan perasaan, mampu bekerja dengan baik dalam menangani dan memanipulasi objek. Strategi kecerdasan ini meliputi strategi keterampilan fisik dalam bidang koordinasi, keseimbangan, daya tahan, kekuatan, kelenturan, dan kecepatan. ${ }^{11}$ Beberapa aktivitas guru dalam mengembangkan strategi kecerdasan ini yaitu bermain perandan demonstrasi.

\section{Strategi Musical Intelligence (Strategi Kecerdasan Musikal)}

Strategi kecerdasan musikal adalah sebuah strategi yang dapat digunakan guru dalam pembelajaran dengan cara menyusun nada atau suara dalam urutan, kombinasi, dan hubungan temporal untuk menghasilkan komposisi yang mempunyai kesatuan dan berkesinambungan atau mengandung irama.

Strategi ini dapat dikombinasikan dengan strategi kinestetik. Kolaborasi ini akan menjadikan pembelajaran efektif dan menjadi media yang baik bagi siswa untuk berimajinasi dan berkreasi tanpa batas. Dengan strategi ini, siswa belajar dengan cara menyenangkan karena dapat membantu siswa untuk mengekspresikan keinginannya. ${ }^{12}$ Penggunaan musik dalam pembelajaran akan meningkatkan hasil pembelajaran karena musik menjadikan suasana dalam pembelajaran menjadi rileks. ${ }^{13}$ Beberapa aktivitas guru dalam mengembangkan strategi kecerdasan ini yaitu bernyanyi dan background musik. 


\section{Strategi Interpersonal Intelligence (Strategi Kecerdasan Interpersonal)}

Strategi kecerdasan interpersonal adalah sebuah strategi kecerdasan yang digunakan oleh guru dalam pembelajaran dengan menekankan pada kebutuhan siswa untuk saling memiliki dan berhubungan dengan orang lain. Strategi kecerdasan interpersonal adalah strategi kecerdasan yang terkait dengan pemahaman sosial, berhubungan dengan orang lain dengan membaca berbagai suasana hati, temperamen, motivasi, dan tujuan orang lain. Guru dapat menerapkan kecerdasan ini dengan mengajak siswa untuk belajar bersama. Belajar bersama merupakan pendekatan pengajaran yang mengintegrasikan berbagai jenis keterampilan sosial dan prestasi akademik. Ketika guru memasang-masangkan atau mengumpulkan siswa sesuai dengan pengelompokan yang direncanakan sebelumnya dan memberikan tugas-tugas kerja bersama yang tepat, mereka memberi kesempatan kepada siswa untuk berinteraksi dengan teman-teman sebaya, mengajar dan belajar dari teman-teman sekelas mereka, mendorong timbulnya ide baru, dan meningkatkan komunikasi di ruang kelas. ${ }^{14}$ Dengan belajar bersama maka siswa memiliki kesempatan untuk memakai berbagai gaya dan kekuatan khusus mereka ke arah penyelesaian tugas kelompok yang beraneka ragam.

Dengan penerapan kecerdasan ini maka para siswa dapat memahami orang lain atau lingkungan sosialnya, dan berinteraksi dengan peserta didik lainnya sehingga dapat mengembangkan tingkat pemahaman baru dalam pembelajaran. Beberapa bagian dari strategi kecerdasan ini adalah jigsaw learning (pembelajaran kooperatif), simulasi, dan peer teaching (mengajar dengan teman sebaya).

\section{Strategi Intrapersonal Intelligence (Strategi Kecerdasan Intrapersonal)}

Strategi kecerdasan intrapersonal adalah sebuah strategi yang diterapkan guru dalam pembelajaran dengan menekankan kepada kemandirian siswa dalam belajar. Tujuan dari strategi ini adalah membuat siswa mampu menyadari keberadaan dirinya secara mendalam baik perasaan terutama mengetahui kelebihan dan kekurangannya, ide-ide, dan tujuan hidupnya. Beberapa aktivitas guru dalam mengembangkan strategi kecerdasan ini yaitu memberikan tugas individual dan melakukan refleksi.

\section{Strategi Natural Intelligence (Strategi Kecerdasan Natural)}

Strategi kecerdasan naturalis adalah sebuah strategi yang digunakan guru dalam pembelajaran yang memanfaatkan lingkungan sebagai sumber pembelajaran. Lingkungan merupakan faktor pendorong yang menjadi penentu dalam meningkatkan pemahaman siswa dalam setiap pembelajaran. Konsep pembelajaran dengan strategi ini memberikan peluang yang sangat besar kepada siswa untuk meningkatkan hasil belajarnya, dan meningkatkan motivasi belajar bagi siswa. ${ }^{15}$

Strategi ini juga biasa diistilahkan sebagai strategi environment learning yaitu strategi pembelajaran dengan mengunjungi suatu tempat yang memiliki manajemen tertentu. Konsepnya adalah get something artinya siswa akan mendapatkan pengeta- 
huan dan informasi dari lingkungan yang dikunjungi. ${ }^{16}$ Aktivitas-aktivitas guru dalam strategi ini adalah karyawisata dan jendela belajar.

\section{Strategi Eksistensialist-Spiritual (Strategi Kecerdasan Spiritual)}

Strategi kecerdasan spiritual adalah salah satu strategi yang digunakan guru dalam pembelajaran dengan menekankan pada konteks yang lebih luas dalam makna dan nilai dengan mengetahui apa yang kita yakini, kepada siapa kita melakukannya dan apa sebenarnya yang ingin kita capai. ${ }^{17}$ Strategi kecerdasan spiritual adalah strategi kecerdasan moral yang mampu memberikan pemahaman yang menyatu dalam diri agar dapat membedakan sesuatu yang benar dengan yang salah atau keliru. ${ }^{18}$

Strategi kecerdasan spiritual adalah strategi yang digunakan oleh guru dengan mengarahkan siswa pada perbuatan baik dengan tujuan akhir adalah dunia transenden, segala sesuatu dikaitkan dengan ketuhanan. Oleh karena itu, dengan menggunakan kecerdasan ini dalam pembelajaran maka siswa tidak akan memecahkan masalah atau persoalan hidup hanya secara rasional atau emosional saja, tetapi ia juga menghubungkannya dengan makna kehidupan secara spiritual. ${ }^{19}$

Guru dapat menerapkan strategi ini dengan senantiasa menyisipkan nasehatnasehat, pelajaran akhlak, moral, dan pengetahuan-pengetahuan keagamaan dalam setiap pembelajarannya. Seorang guru harus memahami hal ini. Oleh karenanya, pendidik tidak hanya memberikan peserta didiknya wawasan hanya sebatas ilmu pengetahuan duniawi, tetapi setiap pembelajaran harus senantiasa disandarkan kepada Si Pemberi Pengetahuan atau Pemilik Ilmu.

Guru berperan dalam mengembangkan kecerdasan spiritual siswa. Oleh karena itu, guru harus merancang dengan baik program pembelajarannya dengan mengnyinergikan kecerdasan siswa dengan cara bertindak sebagai leader. Ia juga harus senantiasa memodelkan tingkah laku sosial yang positif dalam pembelajaran di kelas, membina warga sekolah yang bermoral dengan membantu siswa mengetahui, menghormati, dan menyayangi antarsesama siswa serta senantiasa merasakan bahwa mereka adalah bagian dari kelompok, mengamalkan disiplin bermoral dengan membuat tata tertib di sekolah dan meminta siswa mematuhi peraturan tersebut, memberikan nilai secara objektif dalam proses pembelajaran, membentuk budaya sekolah yang mendukung nilai-nilai yang positif, dan senantiasa berkomunikasi dengan orang tua dan menjadikan mereka sebagai teman dalam membantu siswa belajar. ${ }^{20}$

Agar strategi di atas terwujud, guru harus mengubah paradigma atau pola pikir mereka dalam memandang pembelajaran yang bukan hanya ke arah pencapaian kognitif atau intelektual, melainkan yang terpenting adalah membantu siswa membangun karakternya atau afektifnya dengan cara efektif. Beberapa aktivitas yang dapat dilakukan guru dalam mengembangkan kecerdasan spiritual siswa yaitu pemberian nasihat, memberi keteladanan, dan pembiasaan.

Dalam menerapkan berbagai strategi kecerdasan di atas, tidak hanya terfokus pada satu strategi kecerdasan, tetapi terintegrasi dengan strategi kecerdasan lainnya. Misalnya, strategi kecerdasan linguistik dapat dipadukan dengan kecerdasan interpersonal dalam proses pembelajaran, ataupun strategi kecerdasan lainnya. Dengan 
strategi kecerdasan ini, guru dapat mengembangkan potensi-potensi yang ada pada diri siswa, gaya belajar dan mengajar yang menyenangkan karena tidak hanya terfokus satu kecerdasan, tetapi bisa diintegrasikan dengan kecerdasan lainnya. Oleh karena itu, guru harus menyesuaikan kecerdasan yang dimiliki oleh siswa sebagai bentuk dari gaya belajarnya dan guru harus memiliki kreativitas dalam menerapkan berbagai strategi tersebut.

\section{Kualitas Pembelajaran Pendidikan Agama Islam}

Kualitas atau mutu merupakan proses. Proses mutu memperkaya model perbaikan sekolah dengan memberikan pada profesional pendidikan, perangkat dan teknik yang diperlukan untuk mencapai sasaran yang dibutuhkan. Mutu memfokuskan pada penggunaan data untuk mengefektifkan perubahan. ${ }^{21}$

Kualitas pembelajaran, khususnya pembelajaran PAI dapat dikembangkan dengan model kegiatan pembelajaran yang mengacu pada standar proses. Standar proses meliputi perencanaan proses pembelajaran, pelaksanaan proses pembelajaran, penilaian hasil pembelajaran, dan pengawasan proses pembelajaran untuk terlaksananya proses pembelajaran yang efektif dan efisien..$^{22}$

Kualitas pembelajaran pada umumnya dan PAI pada khususnya dapat dikembangkan juga dengan melibatkan siswa secara aktif, demokratis, mendidik, memotivasi, mendorong kreativitas, dan dialogis. Selanjutnya, dapat dikembangkan dengan tujuan agar siswa mencapai pola pikir dan kebebasan berpikir sehingga dapat melaksanakan aktivitas intelektual berupa berpikir, berargumentasi, mempertanyakan, mengkaji, menemukan dan memprediksi. Juga dapat dikembangkan dengan pemahaman bahwa keterlibatan siswa dalam proses belajar yang dilakukan secara sungguh-sungguh dan mendalam untuk mencapai pemahaman konsep, tidak terbatas pada materi yang diberikan guru. ${ }^{23}$ Dengan demikian, kualitas pembelajaran PAI khususnya, lebih banyak ditentukan oleh peran guru PAI dalam proses pembelajaran.

Berdasarkan uraian di atas, jika ingin meningkatkan kualitas pembelajaran PAI sebagaimana yang diinginkan di atas maka strategi multiple intelligences sangat cocok untuk diterapkan dalam pembelajaran PAI, karena strategi ini lebih banyak menekankan keterlibatan siswa dalam belajar sehingga siswa lebih cepat memahami apa yang diajarkan. Strategi kecerdasan ini juga menunjukkan bahwa siswa mana pun yang diajar dengan cara melibatkan kecerdasannya sendiri yang dominan akan bisa mempelajari, memahami dan menerapkan pengetahuan secara efektif. Dengan strategi multiple intelligences ini, guru akan menemukan dan memanfaatkan berbagai kekuatan terbesar dan gaya belajar paling menyenangkan di dalam diri siswa, sambil meningkatkan keterampilan siswa dalam membaca, berpikir, menulis, berbicara, dan mendengar sebagai keterampilan literasi. ${ }^{24}$

Penerapan strategi multiple intelligences dalam pembelajaran PAI sebagai wujud dalam meningkatkan kualitas pembelajaran PAI. Oleh karena itu, untuk meningkatkan kualitas pembelajaran, maka dibutuhkan perubahan terhadap kualitas sumber daya manusia dalam mengimplementasikan strategi pembelajaran yang digunakan. 
Dengan demikian, guru PAI dapat mengoptimalkan kecerdasan yang dimiliki siswanya dengan menggunakan strategi multiple intelligences.

Strategi pembelajaran multiple intelligences pada praktiknya adalah memacu kecerdasan yang menonjol pada diri siswa seoptimal mungkin, dan berupaya mempertahankan kecerdasan lainnya sesuai dengan standar minimal yang ditentukan oleh sekolah. Penerapan strategi ini akan memberikan keuntungan yang lebih baik bagi siswa, dan siswa akan keluar sebagai individu yang memiliki jati diri, yang potensial pada salah satu atau lebih dari sembilan jenis kecerdasan yang dimilikinya. ${ }^{25}$

Ada dua cara dalam menerapkan strategi ini agar mendapatkan hasil yang maksimal dan menjadikan pembelajaran berkualitas yaitu memberdayakan semua jenis kecerdasan pada setiap mata pelajaran, dan mengoptimalkan pencapaian mata pelajaran tertentu berdasarkan kecerdasan yang menonjol pada masing-masing siswa. ${ }^{26}$

Memberdayakan semua jenis kecerdasan pada setiap mata pelajaran adalah ibarat menginput informasi melalui sembilan jalur ke dalam otak memori siswa. Kemudian, untuk mengoptimalkan pencapaian mata pelajaran tertentu berdasarkan kecerdasan yang menonjol pada masing-masing siswa, dimulai dengan guru mengidentifikasi kecerdasan yang menonjol pada tiap-tiap siswa dan ketika kecerdasan siswa terdeteksi maka dapat dilakukan dengan pendekatan personal atau individual. ${ }^{27}$ Dengan demikian, strategi ini akan menjadikan siswa tidak hanya menguasai konsep pengetahuan semata, tetapi ia juga dapat menerapkan pengetahuannya dalam berbagai aspek kehidupan.

\section{METODE PENELITIAN}

Jenis penelitian ini adalah correlational research yang bertujuan mengetahui hubungan suatu variabel dengan variabel lainnya. Penelitian korelasi ditujukan untuk memprediksi skor subjek pada suatu variabel melalui skor pada variabel lain. ${ }^{28}$ Hubungan antara satu dengan beberapa variabel lain dinyatakan dengan besarnya koefisien korelasi dan keberartian (signifikansi) secara statistik. ${ }^{29}$ Hubungan antara variabel satu dengan variabel lainnya adalah asosiatif-kausalitas, artinya adalah hubungan sebab-akibat yang memiliki variabel independent dan dependent.

Populasi dalam penelitian ini adalah semua guru PAI pada SMP Negeri di Watampone yang keseluruhannya berjumlah 34 orang. Dalam penelitian ini, semua populasi dinyatakan sebagai responden di dalam penelitian.

Data diperoleh dari jawaban responden atas instrumen implementasi strategi multiple intelligences dan rubrik proses pembelajaran. Sebelum digunakan mengumpulkan data, intrumen terlebih dahulu divalidasi dan diukur tingkat reliabilitasnya. Data yang diperoleh dari responden dianalisis dengan analisis koefisien korelasi product moment dengan membandingkan antara nilai $\mathrm{r}_{\text {hitung }}\left(\mathrm{r}_{\mathrm{xy}}\right)$ dan nilai $\mathrm{r}_{\text {tabel }}\left(\mathrm{r}_{\mathrm{t}}\right)$ pada taraf signifikansi $5 \%$ dan $1 \%$. Untuk menguji signifikansinya, kemudian diuji dengan menggunakan uji t. 
Alat analisis yang disebut di atas digunakan untuk menganalisis hipotesis penelitian ini, yaitu: terdapat hubungan antara strategi multiple intelligences terhadap kualitas pembelajaran pada SMPN di Watampone.

\section{HASIL DAN PEMBAHASAN}

\section{Strategi Multiple Intelligences pada SMPN di Watampone}

Salah satu strategi yang diterapkan oleh guru PAI pada SMPN di Watampone yaitu strategi multiple intelligences. Strategi ini menekankan pada beberapa kecerdasan yang dimiliki oleh siswa. Dalam pembelajaran PAI, guru mengajar dengan menekankan pada potensi yang dimiliki siswanya dan mengasah beberapa kecerdasan yang dimiliki oleh siswa dalam pembelajaran. Kecerdasan yang dimaksud adalah kecerdasan linguistik, logis-matematis, visual-spasial, kinestetik, interpersonal, intrapersonal, musikal, naturalis, dan spiritual.

Ada beberapa bentuk strategi multiple intelligences yang diterapkan oleh guru PAI pada SMPN di Watampone dan dirinci pada setiap jenis kegiatan, kemudian diklasifikasikan kedalam jenis kecerdasan yang termasuk sebagai item multiple intelligences. Adapun strategi multiple intelligences yang diterapkan oleh guru PAI pada SMPN di Watampone dengan berbagai cara yaitu:

\section{Strategi Kecerdasan Linguistik}

Strategi ini menekankan pada kecerdasan berbahasa. Strategi ini diterapkan agar siswa memiliki kemampuan dan terampil dalam berbahasa. Strategi kecerdasan linguistik ini digunakan oleh guru dalam pembelajaran PAI melalui penggunaan bahasa dalam mengekspresikan dan menghargai makna yang kompleks. Dalam pembelajaran PAI, guru pada SMPN di Watampone lebih banyak menggunakan buku teks, lembar kerja, menggunakan metode ceramah, bercerita, tanya jawab, active debat, dan curah pendapat untuk mengasah dan membangkitkan kecerdasan linguistik dalam diri setiap siswa.

\section{Strategi Kecerdasan Logis-Matematis}

Strategi kecerdasan logis-matematis digunakan guru PAI dalam pembelajaran melalui pengkategorian hukum bacaan atau tanwin, mengajukan pertanyaan pancingan dan menggunakan metode diskusi untuk memecahkan masalah-masalah yang berkaitan dengan PAI. Dalam hal pengkategorian, guru PAI pada SMPN di Watampone biasanya menggunakan kartu indeks (card sort) dalam pembelajarannya. Kartu indeks ini digunakan untuk materi tertentu seperti bacaan surah-surah pendek dan hukum bacaan nun mati atau tanwin, atau mad dan wakaf.

\section{Strategi Kecerdasan Visual-Spasial}

Strategi ini menekankan pada kecerdasan dalam memberikan gambar-gambar, image-image, dan mentransformasikan dunia visual-spasial. Strategi ini diterapkan agar siswa pada SMPN di Watampone memiliki kemampuan dalam memahami hubungan antara obyek dan ruang. Guru PAI pada SMPN di Watampone menerapkan strategi 
visual-spasial dalam pembelajarannya yaitu dengan cara menampilkan gambargambar yang berkaitan dengan materi yang diajarkannya. Gambar-gambar tersebut seperti gambar tentang peristiwa kada dan kadar Allah swt., gambar wudu, tayamum, dan salat.

\section{Strategi Kecerdasan Kinestetik}

Strategi ini menekankan pada kecerdasan dalam mengubah tubuh dalam bentuk gerakan. Strategi ini diterapkan agar siswa pada SMPN di Watampone memiliki kemampuan dalam menggunakan anggota tubuh untuk memecahkan masalah, dan menciptakan produk atau mengemukakan ide atau emosi. Ada beberapa strategi kecerdasan kinestetik yang diterapkan oleh guru PAI pada SMPN di Watampone yaitu bermain peran dan card-sort sebagai bagian dari kecerdasan logis-matematis.

\section{Strategi Kecerdasan Interpersonal}

Strategi ini menekankan pada kecerdasan dalam berinteraksi secara efektif antar siswa dalam pembelajaran. Strategi ini diterapkan agar siswa pada SMPN di Watampone memiliki kemampuan dalam berinteraksi dengan siswa lain dan menjalin kerjasama dengan siswa lain dalam memecahkan masalah.

Strategi interpersonal ini telah diterapkan oleh guru PAI pada SMPN di Watampone. Strategi interpersonal lebih ditekanan pada pemberian tugas secara kelompok, dan peer teaching (mengajar dengan teman sebaya). Dengan strategi ini, siswa dapat belajar bekerjasama dengan orang lain.

\section{Strategi Kecerdasan Intrapersonal}

Strategi ini menekankan pada kecerdasan dalam memahami diri-sendiri. Strategi ini diterapkan agar siswa pada SMPN di Watampone memiliki kemandirian dalam belajar. Dalam menerapkan strategi intrapersonal, guru PAI pada SMPN di Watampone memberikan kepada siswa tugas secara individual sehingga siswa mampu mengenal, memahami, dan percaya diri terhadap hasil kerja dan hasil karyanya sendiri. Contoh tugas individualnya adalah meminta siswa untuk mencari hurufhuruf wakaf dalam al-Qur'an. Selain tugas individual, guru PAI juga mengekspresikan perasaan, memberikan refleksi, dan evaluasi diri dalam pembelajaran. Dengan strategi ini, siswa dapat belajar memahami dirinya sendiri.

\section{Strategi Kecerdasan Musikal}

Strategi ini menekankan pada kecerdasan nada dan irama. Strategi ini diterapkan agar siswa dapat belajar dengan rileks. Namun, strategi ini tidak banyak diterapkan oleh guru PAI pada SMPN di Watampone. Hanya ada beberapa guru PAI termasuk di SMPN 7 Watampone, SMPN 1 Watampone, dan SMPN 9 Watampone. Di SMPN 7 Watampone, guru PAI menggunakan background musik dalam pembelajarannya. Biasanya musik yang diputar adalah musik yang islami sehingga menyentuh perasaan siswa. Pemutaran musik itu diawal pembelajaran sebagai bagian dari kegiatan pembelajaran pendahuluan. Di SMPN 1 Watampone, guru PAI menggunakan al- 
Qur'an Player, sehingga siswa mudah memahami materi yang berkaitan dengan tema al-Qur' an dan hadis. Di SMPN 9 Watampone juga demikian, guru PAI memutar atau memperdengarkan bacaan surah-surah dalam al-Qur'an tentang bagaimana cara membacanya sesuai dengan kaidah-kaidah tajwid melalui handphone.

\section{Strategi Kecerdasan Naturalis}

Strategi ini menekankan pada kepekaan, kecintaan, dan kepedulian terhadap alam sekitar. Strategi ini digunakan agar siswa pada SMPN di Watampone dapat belajar melalui alam. Strategi naturalis telah diterapkan oleh guru PAI pada SMPN Watampone dengan mengadakan pengamatan terhadap fenomena alam yang terjadi sebagai bentuk kekuasaan Allah swt. Dengan cara ini, maka siswa diberi kesempatan untuk menghargai alam dan memahami dunia alam di sekitarnya. Strategi ini disesuaikan dengan materinya, seperti materi tentang iman kepada Allah swt. dan iman kepada kada dan kadar Allah swt.

\section{Strategi Kecerdasan Spiritual}

Strategi ini adalah strategi yang paling sering diterapkan oleh guru PAI pada SMPN di Watampone, karena memang pelajarannya adalah PAI. Tujuan akhir yang ingin dicapai dalam mata pelajaran ini adalah bagaimana siswa dapat menjadi manusia yang beriman dan bertakwa kepada Allah swt., serta berakhlak mulia. Aktivitas yang sering dilakukan oleh guru PAI adalah dengan memberikan keteladanan, pembiasaan yang baik seperti membaca doa sebelum dan sesudah belajar dan mengajak siswa untuk selalu beramar makruf nahi mungkar.

Demikian beberapa strategi multiple intellegences yang diterapkan guru PAI pada SMPN di Watampone. Dari 9 strategi yang terangkum dalam strategi multiple intelligences, 8 di antaranya umumnya diterapkan guru PAI pada SMPN di Watampone yaitu strategi kecerdasan linguistik, logis-matematis, visual-spasial, kinestetik, interpersonal, naturalis dan spiritual. Sedangkan hanya 1 strategi saja yang pada umumnya tidak diterapkan oleh guru PAI pada SMPN di Watampone yaitu strategi kecerdasan musikal.

\section{Kualitas Pembelajaran Pendidikan Agama Islam pada SMPN di Watampone}

Guru PAI pada SMPN Watampone telah berusaha mengembangkan kualitas pembelajaran PAI dengan mengacu pada standar proses pembelajaran yaitu perencanaan, pelaksanaan, penilaian proses dan hasil, serta pengawasan pembelajaran. Terkait dengan perencanaan, guru PAI membuat perangkat pembelajaran berupa rencana pelaksanaan pembelajaran PAI. Rencana pelaksanaan pembelajaran itulah yang menjadi rujukan guru dalam melaksanakan pembelajaran.

Dalam hal pelaksanaan proses pembelajaran, guru PAI pada SMPN Watampone memulai menyampaikan dengan baik kepada siswa tentang standar kompetensi dan kompetensi dasar yang ingin dicapai setelah selesai proses pembelajaran. Setelah itu, terkait dengan materi pembelajaran, guru PAI memfokuskan materi yang akan 
diajarkan, menghindari pemberian materi yang tidak relevan, memetakan materi pembelajaran, dan menguasai dengan baik materi yang akan diajarkan.

Selanjutnya, dalam hal strategi atau metode pembelajaran, guru PAI pada SMPN Watampone memperhatikan dengan baik strategi yang akan dipakai dimulai dengan memilih strategi atau metode yang tepat yang sesuai dengan materi yang akan diajarkannya, memahami dengan baik karakteristik siswa, potensi atau kecerdasan siswa, mengembangkan dan mengaktualisasikan berbagai potensi atau kecerdasan yang dimiliki siswa, menyesuaikan gaya belajar siswa, menguasai berbagai model dan strategi pembelajaran, mengaplikasikannya, membimbing siswa yang memiliki kesulitan dalam belajar PAI, memotivasi siswa, menciptakan suasana yang menyenangkan, mendiagnosis kesulitan belajar siswa, menciptakan persaingan yang sehat, kerjasama antar siswa, memberikan reinforcement berupa pujian, komentar positif, dan hadiah terhadap keberhasilan siswa, serta memberikan contoh yang baik untuk diteladani bagi siswa SMPN di Watampone.

Selain strategi pembelajaran, guru PAI pada SMPN di Watampone juga sangat memperhatikan alat, media, dan sumber yang akan digunakan dalam pembelajaran PAI mulai dari menguasai alat, media, dan sumber belajar, memanfaatkannya dalam pembelajarannya, mendesain atau merancang sendiri jika memang betul-betul dibutuhkan untuk kepentingan belajar siswa, hingga menerapkannya dalam pembelajaran PAI. Dalam pelaksanaan pembelajaran PAI pada SMPN di Watampone, guru PAI juga memperhatikan evaluasi atau penilaian dalam pembelajaran sebagai bentuk dalam peningkatan kualitas pembelajaran PAI. Hal itu dimulai dengan menguasai berbagai evaluasi atau penilaian dalam pembelajaran, menilai kemampuan siswa secara total, memberikan penilaian bagi siswa dalam belajar dan penilaian yang secara obyektif kepada siswa dan bukan penilaian yang sifatnya subyektif.

Dalam hal pengawasan proses pembelajaran PAI, guru telah dipantau dengan baik oleh Kepala SMPN di Watampone dan Pengawas Satuan Pendidikan pada SMPN di Watampone. Pemantauan dilakukan dengan cara observasi langsung di kelas, memeriksa silabus dan perangkat pembelajarannya, mendokumentasikan perangkat pembelajarannya, sharing dengan guru terkait dengan pengembangan pembelajarannya, konsultasi guru kepada Kepala SMPN di Watampone dan Pengawas Satuan Pendidikan pada SMPN di Watampone, serta Kepala SMPN di Watampone memberikan pelatihan terkait dengan pengembangan kompetensi dan kinerja guru PAI pada SMPN di Watampone.

\section{Korelasi antara Strategi Multiple Intelligences dengan Kualitas Pembelajaran PAI pada SMPN di Watampone}

Berdasarkan hasil dari korelasi strategi multiple intelligences terhadap kualitas pembelajaran PAI pada SMPN di Watampone menunjukkan: 


\begin{tabular}{|ll|r|r|}
\hline & \multicolumn{1}{|c|}{$\begin{array}{c}\text { Kualitas } \\
\text { Pembelajaran }\end{array}$} & $\begin{array}{c}\text { Strategi Multiple } \\
\text { Intelligences }\end{array}$ \\
\hline $\begin{array}{l}\text { Pearson } \\
\text { Correlation }\end{array}$ & $\begin{array}{r}\text { Kualitas Pembelajaran } \\
\text { Strategi Multiple } \\
\text { Intelligences }\end{array}$ & .526 & .526 \\
\hline Sig. (1-tailed) & Kualitas Pembelajaran & & 1.000 \\
& Strategi Multiple &. & .001 \\
& Intelligences & .001 &. \\
\hline $\mathrm{N}$ & Kualitas Pembelajaran & 34 & 34 \\
& Strategi Multiple & 34 & 34 \\
& Intelligences & & \\
\hline
\end{tabular}

Tabel 1. Hasil Kkorelasi Strategi Multiple Intelligences terhadap Kualitas Pembelajaran PAI pada SMPN di Watampone

Dari hasil analisis diperoleh bahwa besarnya koefisien korelasi adalah 0,526 dengan P-value sebesar 0,001. Untuk menentukan koefisien korelasi sebesar 0,526 memiliki keberartian (uji signifikansi) dengan membandingkan $r_{\text {tabel }}$ atau membandingkan koefisien $P$-value dengan taraf signifikansi. Jika dibandingkan dengan $P$-value sebesar 0,001 dan hasil korelasi sebesar 0,526 menunjukkan bahwa P-value memiliki nilai yang lebih kecil dibandingkan hasil korelasi maka dinyatakan signifikan. Sedangkan jika P-value lebih besar dari hasil korelasi, dinyatakan tidak signifikan.

Hasil korelasi di atas juga menandakan bahwa angka korelasi antara strategi multiple intelligences dan kualitas pembelajaran PAI pada SMPN di Watampone tidak bertanda negatif, berarti di antara kedua variabel tersebut terdapat korelasi positif atau korelasi yang berjalan searah. Dengan memperhatikan besarnya $r_{x y}$ yaitu 0,526 yang berkisar antara 0,40-0,70, berarti korelasi positif antara strategi multiple intelligences dengan kualitas pembelajaran PAI pada SMPN di Watampone adalah termasuk korelasi positif yang sedang. Untuk membuktikannya dapat dilihat tabel di bawah ini:

\begin{tabular}{|l|l|}
\hline Besarnya ' $r$ ' Product Moment $\left(\mathrm{r}_{\mathrm{xy}}\right)$ & Interpretasi \\
\hline Antara $0,800-1,00$ & Korelasinya sangat tinggi \\
\hline Antara $0,60-0,799$ & Korelasinya tinggi \\
\hline Antara $0,400-0,599$ & Korelasinya sedang \\
\hline Antara $0,200-0,399$ & Korelasinya rendah \\
\hline
\end{tabular}

Tabel 2.Interpretasi " $\mathrm{r}$ " Product Moment

Selanjutnya jika diinterpretasikan dengan menggunakan Tabel Nilai " $r$ ": $\mathrm{df}=$ $\mathrm{N}-\mathrm{nr}=34-2=32$. Oleh karena $\mathrm{df}=32$ tidak ada dalam daftar Tabel Nilai " $r$ " product moment maka diambil angka yang lebih dekat dari 32 yaitu $\mathrm{df}=30$, pada taraf signifikansi $5 \%$ diperoleh $r_{\text {tabel }}=0,349$, sedangkan pada taraf signifikansi $1 \%$ diperoleh $\mathrm{r}_{\text {tabel }}=0,449$. Untuk membuktikanya dapat dilihat tabel berikut: 


\begin{tabular}{|l|l|l|}
\hline \multirow{2}{*}{\begin{tabular}{l} 
df $\begin{array}{l}\text { (degress of freedom) } \\
\text { atau } \\
\text { db. (derajat bebas) }\end{array}$ \\
\cline { 2 - 3 }
\end{tabular}} & \multicolumn{2}{|l|}{ Banyak Variabel yang dikorelasikan } \\
\cline { 2 - 3 } & $5 \%$ & $1 \%$ \\
\hline 29 & 0,355 & 0,456 \\
30 & $\mathbf{0 , 3 4 9}$ & $\mathbf{0 , 4 4 9}$ \\
35 & 0,325 & 0,418 \\
\hline
\end{tabular}

Tabel 3. Nilai Koefiensien Korelasi ' $r$ ' Product Moment dari Pearson untuk Berbagai df

Hasil tersebut menandakan bahwa ternyata bahwa $r_{x y}$ lebih besar dari $r_{t}$ baik pada taraf signifikansi $5 \%$ maupun $1 \%$. Oleh karena $r_{x y}$ lebih besar dari $r_{t}$ maka hipotesis alternatif diterima sedangkan hipotesis nihil ditolak. Selanjutnya, jika dibandingkan dengan $t_{\text {hitung }}$ dan $t_{\text {tabel, }}$, dasar pengambilan keputusannya adalah:

Jika $t_{\text {hitung }}<\mathrm{t}_{\text {tabel}}$, maka $\mathrm{H}_{\mathrm{o}}$ diterima

Jika $t_{\text {hitung }}>t_{\text {tabel, }}$ maka $\mathrm{H}_{\mathrm{o}}$ ditolak

Oleh karena $t_{\text {hitung }}>t_{\text {tabel }}$ atau $3,50>2,42$, maka $H_{o}$ ditolak. Dengan demikian, ada korelasi yang nyata antara strategi multiple intelligences dengan kualitas pembelajaran PAI pada SMPN di Watampone atau strategi multiple intelligences benar-benar berkorelasi dengan kualitas pembelajaran PAI pada SMPN di Watampone. Dengan demikian, terjadi korelasi positif antara strategi multiple intelligences yang digunakan guru PAI pada SMPN di Watampone dengan kualitas pembelajaran PAI pada SMPN di Watampone. Korelasinya adalah korelasi positif meyakinkan. Jika semua guru pada SMPN di Watampone menerapkan strategi ini, kualitas pembelajaran yang lain juga akan meningkat. Akan tetapi, dalam menerapkannya jangan hanya terfokus pada satu strategi, seharusnya guru memvariasikannya agar strategi itu tidak monoton dan membuat siswa jenuh terhadap satu strategi.

Dari uraian ini dapat dipahami bahwa berbagai bentuk penerapan strategi pembelajaran khususnya strategi multiple intelligences yang digunakan guru PAI pada SMPN di Watampone dalam proses pembelajaran sangat penting. Hal itu akan meningkatkan keberhasilan pencapaian tujuan pembelajaran PAI dan kualitas pembelajaran PAI yang ingin dicapai. Oleh karenanya, penerapan strategi ini bukanlah satusatunya indikator dalam meningkatkan kualitas pembelajaran PAI pada SMPN di Watampone, boleh jadi ada faktor lain yang juga dapat meningkatkan kualitas pembelajaran PAI.

\section{SIMPULAN}

Berdasarkan hasil penelitian di atas, dapat disimpulkan bahwa terdapat hubungan positif antara strategi multiple intelligences dengan kualitas pembelajaran PAI pada SMPN di Watampone. Korelasinya ditunjukkan oleh hasil olah data yang menunjukkan $r_{x y}$ lebih besar dari $r_{t}$ baik pada taraf siginifikansi $5 \%$ maupun $1 \%$. Penjelasan ini mengindikasikan bahwa penggunaan strategi multiple intelligences 
efektif terhadap peningkatan kualitas pembelajaran pada bidang studi PAI. Di samping itu, korelasi antara kedua variable menunjukkan korelasi positif.

Kesimpulan tersebut menunjukkan apabila aspek kecerdasan jamak dipertimbangkan di dalam pembelajaran, maka akan berpengaruh secara positif mutu proses pembelajaran. Artinya, semakin besar perhatian terhadap perbedaan kecerdasan dominan peserta didik, semakin besar pula peluang perbaikan mutu proses pembelajaran.

\section{CATATAN AKHIR}

1. Oemar Hamalik, Proses Belajar Mengajar, cet. VII; Jakarta: Bumi Aksara, 2008, h. 77.

2. J.R. David dalam Wina Sanjaya, Strategi Pembelajaran: Berorientasi Standar Proses Pendidikan, cet. V; Jakarta: Kencana, 2008, h.126.

3. E. Mulyasa, Menjadi Guru Profesional: Menciptakan Pembelajaran Kreatif dan Menyenangkan, cet. VII; Bandung: Remaja Rosdakarya Offset, 2008, h. 36.

4. Made Wena, Strategi Pembelajaran Inovatif Kontemporer: Suatu Tinjauan Konseptual Operasional, Jakarta: Bumi Aksara: 2011, h. 2-3.

5. Wikipedia, The Free Encyclopedia dengan judul Theory of Multiple Intellegences, didownload pada tanggal 11 November 2009. Lihat juga Anna Guigno, Multiple Intelligences: A Theory for Everyone, by Education World, didownload pada tanggal 11 November 2009.

6. Munif Chatib, Strategi Mengajar Multiple Intelligences untuk Semua Jenjang Pendidikan, Didownload Pada Tanggal 3 Maret 2014.

7. Thomas Armstrong, Multiple Intelligences in The Classroom, terj. Dyah Widya Prabaningrum, Kecerdasan Multiple di dalam Kelas, cet. I; Jakarta Barat: Indeks, 2013, h. 61.

8. Ibid., h. 62.

9. Julia Jasmine, Profesional's Guide: Teaching with Multiple Intelligence, terj. Purwanto, Mengajar dengan Metode Kecerdasan Majemuk: Implementasi Kecerdasan Majemuk, cet. I; Bandung: Nuansa, 2007, h. 249.

10. Agus Effendi, Revolusi Kecerdasan Abad 21: Kritik MI, EI, SQ, AQ dan Successful Intelligence atas IQ, cet. I; Bandung: Alfabeta, 2005, h. 155.

11. Ansharullah, Pendidikan Islam Berbasis Kecerdasan Jamak: Multiple Intelligences, cet. II; Jakarta: Systemic Technique of English Program, 2013, h. 116.

12. Suparman S., Gaya Mengajar yang Menyenangkan Siswa, cet. I; Yogyakarta: Pinus Book Publisher, 2010, h. 183.

13. Jack C., Ricards, Approach and Method in Language Teaching, Cambridge University Press, Cambridge, 1986, h. 143.

14. Evelyn William English, Gift of Literacy for the Multiple Intelligences Classroom, terj. Fuad Ferdinan, Mengajar dengan Empati: Panduan Belajar Mengajar yang Tepat dan Menyeluruh untuk Ruang Kelas dengan Kecerdasan Beragam, cet. III; Bandung: Nuansa Cendikia, 2012, h. 20.

15. Hamzah B. Uno dan Nurdin Mohamad, Belajar dengan Pendekatan PAILKEM, cet. III; Jakarta: Bumi Aksara, 2012, h. 148.

16. Munif Chatib, Gurunya Manusia: Menjadikan Semua Anak Istimewa dan Semua Anak Juara, cet. I; Bandung: Kaifa, 2011, h. 187. 
17. Nur Oktavia Hidayati, Cara Mengembangkan dan Melatih Kecerdasan Spritual, Blog. Spritual Quotient,lathifaniazka.blogspot.com/2012/12/cara-mengembangkan-dan-melatih. html?m =1. (17 April 2014).

18. Simon M. Tampubolon, Kecerdasan Spiritual sebagai Kecerdasan Utama dan Modal Utama Kehidupan, Blog. Keutamaan Kecerdasan Spiritual. logoscandletree.wordpress.com /2012/ 10/05/16. (17 April 2014).

19. Suparman S., op. cit., h. 84-85.

20. Abd. Kadim Masaong dan Arfan A. Tilomi, Kepemimpinan Berbasis Multiple Intelligence: Sinergi Kecerdasan Intelektual, Emosional dan Spiritual untuk Meraih Kesuksesan yang Gemilang, cet. I; Bandung: Alfabeta, 2011, h. 212.

21. Jerome S. Arcaro, Quality Education: An Implementation Handbook, terj. Yosal Iriantara, Pendidikan Berbasis Mutu: Prinsip-Prinsip Perumusan dan Tata Langkah Penerapan, cet. IV; Yogyakarta: Pustaka Pelajar, 2007, h. 47.

22. Peraturan Pemerintah RI Nomor 32 tahun 2013 tentang Perubahan atas Peraturan Pemerintah Nomor 19 Tahun 2005 tentang Standar Nasional Pendidikan, Bab 19 Ayat 3.

23. Peraturan Menteri Pendidikan Nasional RI Nomor 19 Tahun 2007 tentang Standar Pengelolaan Pendidikan oleh Satuan Pendidikan Dasar dan Menengah..

24. Evelyn William English, Gift of Literacy for the Multiple Intelligences Classroom, terj. Fuad Ferdinan, Mengajar dengan Empati: Panduan Belajar Mengajar yang Tepat dan Menyeluruh untuk Ruang Kelas dengan Kecerdasan Beragam, h. 16-17

25. "Strategi Pembelajaran Multiple Intelligence (MI) untuk Pencapaian Kompetensi dalam Pembelajaran," Error! Hyperlink reference not valid. (25 April 2014).

26. "Dwi Hastuti Pungkasari", Strategi Pembelajaran Multiple Intelligence (MI) untuk PencapaianKompetensidalamPembelajaran.http://dwipungka.blogspot.com/2011/11/strateg i-pembelajaran-berbasis-multiple.html? $\mathrm{m}=1$ (25 April 2014)..

27. "Strategi Pembelajaran Multiple Intelligence (MI) untuk Pencapaian Kompetensi dalam Pembelajaran,"Error! Hyperlink reference not valid. (25 April 2014).

28. Emzir, Metode Penelitian Pendidikan: Kuantitatif dan Kualitatif, Jakarta: PT RajaGrafindo Persada, 2009, h. 47

29. Nana Syaodih Sukmadinata, Metode Penelitian Pendidikan, cet. IV; Bandung: Remaja Rosdakarya, 2008, h. 56.

\section{DAFTAR PUSTAKA}

Ansharullah. Pendidikan Islam Berbasis Kecerdasan Jamak: Multiple Intelligences. Cet. II; Jakarta: Systemic Technique of English Program, 2013.

Arcaro, Jeremo S. Quality Education:An Implementation Handbook, terj. Yosal Iriantara, Pendidikan Berbasis Mutu: Prinsip-Prinsip Perumusan dan Tata Langkah Penerapan. Cet. IV; Yogyakarta: Pustaka Pelajar, 2007.

Armstrong, Thomas. Multiple Intelligences in The Classroom, terj. Dyah Widya Prabaningrum dengan judul Kecerdasan Multiple di dalam Kelas. Cet. I; Jakarta Barat: Indeks, 2013.

B. Uno, Hamzah dan Nurdin Mohamad. Belajar dengan Pendekatan PAILKEM. Cet. III; Jakarta: Bumi Aksara, 2012.

Chatib, Munif. Gurunya Manusia: Menjadikan Semua Anak Istimewa dan Semua Anak Juara. Cet. I; Bandung: Kaifa, 2011. . Strategi Mengajar Multiple Intelligences untuk Semua Jenjang Pendidikan. Didownload 
Pada Tanggal 3 Maret 2014.

David, J.R. dalam Wina Sanjaya. Strategi Pembelajaran: Berorientasi Standar Proses Pendidikan. Cet. V; Jakarta: Kencana, 2008.

Effendi, Agus. Revolusi Kecerdasan Abad 21: Kritik MI, EI, SQ, AQ dan Successful Intelligence atas IQ. Cet. I; Bandung: Alfabeta, 2005.

Emzir. Metode Penelitian Pendidikan: Kuantitatif dan Kualitatif. Jakarta: RajaGrafindo Persada, 2009.

English, Evelyn William. Gift of Literacy for the Multiple Intelligences Classroom, terj. Fuad Ferdinan, Mengajar dengan Empati: Panduan Belajar Mengajar yang Tepat dan Menyeluruh untuk Ruang Kelas dengan Kecerdasan Beragam. Cet. III; Bandung: Nuansa Cendikia, 2012.

Guigno, Anna. Multiple Intelligences: A Theory for Everyone, by Education World, didownload pada tanggal 11 November 2009.

Hamalik, Oemar. Proses Belajar Mengajar. Cet. VII; Jakarta: Bumi Aksara, 2008.

Hidayati, Nur Oktavia.Cara Mengembangkan dan Melatih Kecerdasan Spritual, Blog. Spritual Quotient,lathifaniazka.blogspot.com/2012/12/cara-mengembangkan-dan-melatih. html?m =1. (17 April 2014)

Jasmine, Julia. Profesional's Guide: Teaching with Multiple Intelligence diterjemahkan oleh Purwanto dengan judul Mengajar dengan Metode Kecerdasan Majemuk: Implementasi Kecerdasan Majemuk. Cet. I; Bandung: Nuansa, 2007.

Masaong, Abd. Kadimdan Arfan A. Tilomi. Kepemimpinan Berbasis Multiple Intelligence: Sinergi Kecerdasan Intelektual, Emosional dan Spiritual untuk Meraih Kesuksesan yang Gemilang. Cet. I; Bandung: Alfabeta, 2011.

Mulyasa, E. Menjadi Guru Profesional: Menciptakan Pembelajaran Kreatif dan Menyenangkan. Cet. VII; Bandung: Remaja Rosdakarya Offset, 2008.

Peraturan Pemerintah RI Nomor 32 tahun 2013 tentang Perubahan atas Peraturan Pemerintah Nomor 19 Tahun 2005 tentang Standar Nasional Pendidikan, Bab 19 Ayat 3.

Peraturan Menteri Pendidikan Nasional RI Nomor 19 Tahun 2007 tentang Standar Pengelolaan Pendidikan oleh Satuan Pendidikan Dasar dan Menengah.

Pungkasari, Dwi Hastuti. Strategi Pembelajaran Multiple Intelligence (MI) untuk Pencapaian Kompetensi dalam Pembelajaran. http://dwipungka.blogspot.com/2011/11/strategipembelajaran-berbasis-multiple.html?m=1 (25 April 2014).

Ricards, Jack C. Approach and Method in Language Teaching. Cambridge University Press, Cambridge, 1986.

Sukmadinata, Nana Syaodih. Metode Penelitian Pendidikan. Cet. IV; Bandung: Remaja Rosdakarya, 2008.

Suparman S.Gaya Mengajar yang Menyenangkan Siswa. Cet. I; Yogyakarta: Pinus Book Publisher, 2010,

Strategi Pembelajaran Multiple Intelligence(MI) untuk Pencapaian Kompetensi dalam Pembelajaran,"'Error! Hyperlink reference not valid. (25 April 2014

Tampubolon, Simon M. Kecerdasan Spiritual sebagai Kecerdasan Utama dan Modal Utama Kehidupan, Blog. Keutamaan Kecerdasan Spiritual. logoscandletree.wordpress.com /2012/ 10/05/16. (17 April 2014)

Wena, Made. Strategi Pembelajaran Inovatif Kontemporer: Suatu Tinjauan Konseptual Operasional. Jakarta: Bumi Aksara: 2011.

Wikipedia. The Free Encyclopedia dengan judul Theory of Multiple Intellegences. Didownload pada tanggal 11 November 2009. 